УДК 811.111'25:35.4(045)

DOI https://doi.org/10.24919/2663-6042.15.2021.8

\title{
STYLISTIC AND TRANSLATION ASPECTS OF ENGLISH MILITARY TEXTS
}

\author{
Dolynskiy Ye. V. \\ Khmelnytsky National University
}

An article deals with the study of military translation as one of the types of special translation with a pronounced military communicative function. The main stylistic and translation aspects of English military texts translation are considered, namely: terminology, brevity, specificity of wording and clear presentation of the material, which ensures its logical sequence, clear demarcation of opinions, and ease of perception of transmitted information without emotional means of expression. The activity of a military translator, which requires special training, skills and abilities, has been identified. A military translator must be a universal, not a narrow specialist.

Stylistic and lexical methods for translating of English military terminology were also identified. The style of English military texts is not homogeneous; for the most part in military texts the presentation of the material takes place in dry official clerical language. It is noted that in terms of linguistics, vocabulary of English military texts is a set of all elements of military communication that reflect the influence of cultural, historical, territorial, specialized and other extra linguistic factors, reflected in specific expressions that can sometimes create a great linguistic and cultural barrier to translation.

The article describes stylistic and translation aspects of interpretation of professional terminology in English military texts, namely: loan translation, transcription, equivalent translation, descriptive translation and explication. The correct translation of English military texts means not only accurate transmission of the content of the material, but also careful transmission of its structural form, sequence of presentation and a number of other factors that may be considered unnecessary, formal, but of great importance to the military specialist.

Dealing with military literature, you should first understand its main and important stylistic features - brevity of interpretation and clarity of wording. The translation of military texts needs perfect and clear knowledge of terminology. Military term precisely expresses the idea or conception, the process or the name of something is usually mono semantic. Military terms are united into the terminological system. Such terminology is formed by the great number of widely used words, which have several meanings apart from their basic ones.

Key words: military translation, translation of terms, military terminology, stylistic features of military texts.

Долинський $\boldsymbol{G}$. В. Стилістичні та перекладацькі аспекти англійських військових текстів. Статтю присвячено дослідженню військового перекладу як одного з видів спеціального перекладу з яскраво вираженою військовою комунікативною функиією. Розглянуто основні стилістичні та перекладацькі аспекти перекладу англійських військових текстів, а саме: термінологічність, стислість, чіткість і конкретність формулювань та точне і чітке викладення матеріалу, щзо забезпечує його логічну послідовність, відмежування однієї думки від іншої, легкість сприйняття переданої інформації за умови здебільшого відсутності емочійних виразних засобів. Наголошено, що діяльність військового перекладача вимагає спеціальної підготовки, навичок $і$ вмінь. Військовий перекладач має бути універсальним, а не вузькопрофільним фахівцем.

Визначено стилістичні та лексичні способи перекладу англійської військової термінології. Стиль англійських військових текстів не є однорідним, викладення матеріалу у військових текстах переважно відбувається сухою, офіційно канцелярською мовою. Зауважено, щуо в контексті лінгвокраӥнознавства лексика англійських військових текстів - це сукупність усіх елементів сфери військового спілкування, які віддзеркалюють вплив культурних, історичних, територіальних, вузькоспеціальних та інших екстралінгвальних факторів, щчо знаходять свій словесний вияв у конкретних виразах, які іноді здатні створити нездоланний лінгвокультурний бар'єр для перекладача.

У статті описано стилістичні та перекладацькі аспекти інтерпретації фахової термінологї в англійських військових текстах, зокрема: калькування (дослівний переклад), транскрибування, еквівалентний переклад, описовий переклад та експлікацію. Адекватність перекладу англійських військових текстів передбачає не тільки точне відтворення змісту матеріалу, але й ретельну передачу його структурної форми, послідовності викладу та низку інших факторів, які можуть вважатися не потрібними, формальними, але мають велике значення для військового фахівия.

Акцентовано на важливості врахування у процесі перекладу військових текстів основних стилістичних особливостей: лаконічності висловлювань та чіткості формулювань. Для перекладу військових текстів перекладач повинен володіти глибокими знаннями термінологї. Військовий термін точно виражає ідею чи концепцію, процес або назву чогось і зазвичай є моносемантичним. Військові терміни об'єднані в термінологічну систему, шо складається з великої кількості широко вживаних слів, які мають декілька значень, крім основного.

Ключові слова: військовий переклад, переклад термінів, військова термінологія, стилістика військових текстів. 
Defining the problem and argumentation of the topicality of the consideration. Military translation has developed over the centuries. Since the mankind evolution, the sphere of military translation has developed extremely, and even today military terminology and its language structure are growing every day. The content of modern military terminology is quite dynamic. It is constantly changing and acquiring new qualities. Different terms appear due to the emergence of new weapons, military equipment and renovation of military force $[12,34]$.

In military translation, the accuracy of translation is of great importance, since the translated material can serve as a basis for making important decisions, conducting military operations, etc. Therefore, the adequacy of the translation of military materials involves not only the accurate transfer of content, but also a more careful transfer of its structural form, order of parts and placement of material, sequence of presentation and a number of other factors that may seem unnecessary, formal, but important for the military specialist. For example, in military documents the order of paragraphs and subparagraphs, their designation (Arabic numerals and letters of the Latin alphabet), the accuracy of dates and times, coordinates, geographical names, numbering and names of parts and divisions and other data [4, 19].

Analysis of recent research and publications. A few scientific and methodical works of the last century (L. L. Neliubin, H. M. Strelkovskyi, R. K. MiniarBieloruchev, M. Ya. Tsvillinh, L. K. Latyshev, A. F. Shyriaiev, V. M. Shevchuk), as well as modern scientific research (O. H. Kniazieva, M. K. Harbovskyi and E. M. Mishkurov, P. P. Banman, N. M. Romanenko and E. Shahardynova, E. K. Shoryn and others) are devoted to the problems of military translation. In Ukraine, certain aspects of military translation were studied by V. V. Balabin, P. A. Matiusha, M. B. Bilan, S. Ya. Yanchuk, B. A. Dzis, L. M. Honcharuk, O. M. Nikiforova and others [1, 67; 2, 99-100].

Setting the goals and tasks of the article. The goal of the article is to reveal the stylistic and lexical features of the translation of military terminology and its reproduction in texts on various topics. The main tasks of the article are: to reveal the concept of "military terminology" and to define the responsibilities of a military translator; to determine stylistic and lexical ways of translating military terminology.

The outline of the main research material. Military translation is a very specific discipline. This sometimes requires detailed knowledge of military science and even hierarchical structures in the army.

Military translation is a type of special translation with a pronounced military communicative function. A distinctive feature of military translation is the great terminology and accurate and clear presentation of the material in the relative absence of expression of emotional means.

A thorough knowledge of military terminology is required for a military translator. All military texts are full of specific military and technical terms, abbreviations and idioms.

Many of these terms and definitions can have a huge variety of interpretations, depending on the context. There may also be a case where there is a need to translate idiomatic military expressions and slang. In this case, youneed to rely on vocabulary as well as your own skills [5, 97].

L. L. Neliubin believes that all military materials differ from other materials by the saturation of special military vocabulary, extensive use of military and scientific and technical terminology; the presence of a certain amount of military translation; some aspects of variability of stable phrases; military characteristic only for communication nomenclature and special abbreviations and symbols, only used in military materials; and in terms of syntax extensive use of elliptical (especially in military documentation) and cliché constructions. The researcher distinguishes in military translation military-artistic, military-political, military-scientific, military-technical materials, acts of military administration (various military documents) [9].

The translation of military terminology creates great difficulties, because the correct translation cannot be done without a careful, sometimes even etymological analysis of its components. Usually the translation of this group of terms is achieved through: descriptive translation; loan translation; partial or complete transliteration; transliteration or literal translation; transcription $[5,100]$.

It should be noted that the main translation error of such terms is that translators sometimes try to find a literal correspondence of a foreign term to Ukrainian documents.

This approach is not entirely correct, because, firstly, it erases the specifics of the realities of a foreign army, and secondly, there may be an error due to the fact that these terms may express concepts specific only to this army, and therefore not to correspond to the realities accepted in the Ukrainian army $[5,100 ; 11]$.

L. L. Nelyubin compiled his own classification of combat documents according to their type and nature into the following groups: orders, directives, official letters, memos, summaries, negotiation tables, codes, call sign tables and other operational and tactical documents, the value of which is determined by their novelty; officially printed publications (charters, guidelines, instructions); geographical documents (maps, diagrams, etc.); personal documents and insignia of connections; diaries, notebooks, personal notes and photos; private correspondence; newspapers and other printed publications; announcement of civil authority [9, 139-140].

One of the important problems of achieving the adequacy of translation is transfer of the original style. The stylistic aspect of translation is the correct choice of lexical and grammatical means in accordance with the general functional and communicative orientation of the original, taking into account the existing literary norms of the language in which the translation is performed. The concept of "style" is understood as a variety and modification of literary language; the manner of speech expression in different areas, conditions, forms (oral and written) of communication; art of the word. L. L. Nelyubin has his own definitions of concepts: "style", "language style" and "speech style" [10].

The style of military materials is not homogeneous. In military texts, there are two tendencies in the presentation of material: either in official clerical 
language with the use of complicated, often archaic inversions and constructions, or in simple, colloquial, even familiar language $[5,98]$.

The latter tendency is observed mainly in military and military-technical materials for ordinary and non-commissioned officers. This tendency is primarily due to the desire to make official statutory materials and complicated technical texts more accessible to the majority of servicemen. Because of this, many military journalistic texts have explanatory illustrations, tables, diagrams and charts that help to bring to the reader the essence of the issue being taught. In all cases, the translator should seek to convey the original material, using the Ukrainian military style of presentation of relevant materials, neutralizing in the Ukrainian language unnecessary imagery and slang elements existing in the original, because they are not inherent in Ukrainian military materials $[5,97]$.

Most military texts are divided into four functional styles: Conversational (casual style, informal communication); Formal business (formal communication style); Information and journalistic (style of media, press or media); Scientific and technical (style of scientific and technical literature) $[9,24]$.

There are the following technical and stylistic techniques:

1. Logical segmentation of the text. This technical and stylistic technique is used to express the logic and clarity of expression. It is achieved by clear segmentation of the text into subsections, items, paragraphs, and so on.

This technique is especially evident in combat documents, where the sequence of items is strictly regulated and the number of the paragraph in the combat order determines its content.

In military-scientific and military-technical texts, the method of segmentation is used without special regulation by paragraphs, but it is clearly traced in all military texts in the form of their division into parts, sections, chapters, paragraphs and indents. Logical segmentation of the text is also facilitated by its graphic design that is different font selections. In the statutory literature, segmentation is often used in the form of listing individual items from a new line beginning with a dash.

2. The second technique, which provides a certain stylistic color of the language work, could be called a communicative actualization. The question of the actual division of the proposal is very important, which is why it was the subject of lively discussion among the representatives of the Prague Linguistic Circle [1; 7].

The stylistic definiteness of a military text is organically connected with its semantic and structural organization. The military text already has the corresponding stylistic marking at the level of supra-phrase unity (paragraph), which is characterized by a set of certain stylistic features.

However, the stylistic definiteness of a paragraph is not always fully predictive of the stylistic essence of the entire military text. Such cases are most often observed in military-political texts. Depending on the speech situation, military texts can be produced in both written and oral versions, but most types of military texts exist in written forms $[1,70]$.
V. M. Lisovskyi notes that the main stylistic features of military-technical texts are accurate and clear presentation of the material, in the almost complete absence of those expressive elements that give the speech emotional expressiveness. The main emphasis is on the logical, not the emotional side of the presentation. In military texts there are also no methods of general imagery of utterance, which are completely unnecessary when describing various technical devices. However, this cannot be said of the military-technical terminology itself. Sometimes technical terms already have imagery by their origin, but due to frequent use the imagery is usually erased, and the term itself is perceived without figurative characteristics $[6 ; 7,303]$.

Military vocabulary is divided into three main groups:

1) Military terminology, which means concepts that are directly related to military affairs, the armed forces, methods of armed struggle, etc.;

2) Military-technical terminology, which includes scientific and technical terms;

3) Emotionally colored military vocabulary (slang), represented by words and phrases that are often used mainly in the spoken language of American servicemen and are in fact stylistic synonyms of the relevant military terms.

The correct translation of military materials depends to a large extent on the correct translation of terms, because most of the military vocabulary is represented by military and military-technical terms that represent the maximum semantic load $[8,66-67 ; 10,13-14]$.

Let's consider some examples of military texts translation, as well as analyze the ways in which military terminology was translated, namely: loan translation, transcription, equivalent translation, descriptive translation and explication.

1. The internal ballistics characteristics of barreled weapon depend on chemical composition of propelling charge, its burning velocity, powder grains size and shape and confinement. The length of barrel and chamber volume, are also influenced the features Внутрішні балістичні характеристики стволової зброї залежать від хімічного складу порохового заряду твердого ракетного палива, швидкості його горіння, зернистості пороху, форми та щцільності заряджання. Довжина ствола та об'єм камери також впливають на иі якості.

Analyzing our translation, we can see that the term "barreled weapon" was translated using an equivalent translation. After all, the word "barreled" translates as: "бочкоподібний". In this case, we need to find the correct equivalent in the military dictionary.

The term "propelling charge" was translated by descriptive translation. After all, if we translate by the method of tracing, for example, the term will lose its meaning in the sentence.

The term "confinement" is translated by explication. In this case, the lexical unit of the original language is replacedby aphrase thatconveysitsmeaning. Inloantranslation, the term "confinement" means «ув'язнення» or «обмеження», this does not fit the context of the sentence.

"Length of barrel" was translated using the method of loan translation. 
2. Close to the muzzle, the out flowing gases have a much higher velocity than the projectile; consequent$l y$, they overtake and pass the projectile - Близько до вихідного отвору вогнепальної зброї, порохові гази мають значно більшу швидкість ніж снаряд; тому вони обганяють та оминають снаряд.

The term "muzzle" was translated by descriptive translation so that readers can understand what the text is about. After all, the word "muzzle" literally means «дуло».

The phrase "out flowing gases" is translated using an equivalent translation method. The equivalent was found in military dictionaries. Such translation is more appropriate to the context of the sentence.

3. There are three basic types of operation for semiautomatic and automatic small arms-gas operation, recoil operation, and blow back operation-Iснує три основні види операчій для напівавтоматичної та автоматичної стрілецької зброї - принцип відведення порохових газів, принцип використання сили віддачі та принцип використання віддачі затвору.

The term "small arms" was translated using an equivalent translation method.

In this case, you need to refer to the military dictionary to find the equivalent of the word "small".

The terms "gas operation", "recoil operation" and "blow back operation" are translated using the descriptive method. This was done in order to clarify the meaning of the phrase.

1. Hammer or, in some cases, the bolt itself is held in a cocked position by a piece called the sear-Молоточок, або в деяких випадках, сам затвор, утримується у зведеному положенні шматочком, який називається шептало.

The term "cocked position" is translated using the loan translation method. This kind of translation gives the correct semantic meaning in the sentence.
The term "sear" is translated using an equivalent translation method. The word itself means «автоматичний спуск» or «спусковий важіль», but with the help of "military slang", military dictionaries suggest only such an equivalent as «шептало».

2. Antitank guided mortar projectile is called a "firing bomb mortars" because it fires by missiles - Протитанкова керована мінометна міна називається «бомбометом», оскільки вона стріляє ракетними снарядами.

The term "anti tank guided mortar projectile" was translated by loan translation.

The term "firing bomb mortars" is translated using an equivalent method of translation and omission, for a clearer meaning of the term.

Conclusions and directions for further research in this area. All military texts are full of specific military and technical terms, abbreviations and idioms. Many of these terms can have a huge variety of interpretations, depending on the context. The style of transmission in the Ukrainian language must comply with the norms of the "military" language adopted for the relevant type of documents. In these cases, the translator should try to convey the original material, using the Ukrainian military style of the relevant material's presentation $[5,98]$.

The article identified methods of military terminology translation, namely: loan translation, transcription, equivalent translation, descriptive translation and explication. Most military terms and abbreviations are translated by means of the equivalent translation and tracing method, and the least by the transcoding method. In order to translate military terms clearly and intelligibly, it is necessary to constantly refer to military dictionaries and information resources on the Internet.

Prospects for further research are the further study of military abbreviations examples and the analysis of ways of their translation.

\section{BIBLIOGRAPHY}

1. Балабін В. В. Жанрово-стильова специфіка військового перекладу. Науковий вісник Міжнародного гуманітарного університету. Серія : Філологія. Київ, 2018. № 34. Т. 2. С. 67-73.

2. Балабін В. В. Об'єкт і предмет теорії військового перекладу. Науковий вісник Міжнародного гуманітарного університету. Серія : Філологія. Київ, 2017. № 31. Т. 3. С. 97-100.

3. Балабін В. В., Лісовський В. М., Чернишов О. О. Основи військового перекладу (англійська мова) : підручник. Київ : ВІКНУ, 2008. 587 с.

4. Бархударов Л. С. Язык и перевод (Вопросы общей и частной теории перевода). Москва : Международные отношения, $1975.240 \mathrm{c}$.

5. Зайцева М. О. Особливості перекладу термінів у текстах на військову тематику. Науковий часопис НПУ імені М. П. Драгоманова. Серія 9 : Сучасні тендениії розвитку мов. Київ, 2013. Вип. 10. С. 96-102.

6. Лісовський В. М. Військово-технічний переклад (англійська мова) : підручник / за ред. В. В. Балабіна. Київ : ВІКНУ, 2010. $950 \mathrm{c}$.

7. Лісовський В. М. Сутність поняття «військово-технічний текст». Молодіжна військова наука у Київському національному університеті імені Тараса Шевченка : тези доп. всеукр. наук.-практ. конференції молодих вчених, ад’юнктів, слухачів, курсантів і студентів (м. Київ, 26 квіт. 2018 р.). Київ : ВІКНУ, 2018. С. 302-303.

8. Мальцев Д. Д. Особливості перекладу військової термінології. Дебют : зб. тез доповідей студентів факультету грецької філології за результатами участі в Декаді студентської науки 2017 / за заг. ред. докт. політ. наук, проф. К. В. Балабанова, докт. екон. наук, проф. О. В. Булатової. Маріуполь, 2017. С. 65-68.

9. Нелюбин Л. Л. Перевод боевых документов армии США. Изд. 2-е, перераб. и доп. Москва : Воениздат, 1989. 190 с.

10. Нелюбин Л. Л., Дормидонтов А. А., Васильченко А. А. Учебник военного перевода. Москва : Воениздат, 1981. $106 \mathrm{c}$.

11. Пумпянский А. Л. Чтение и перевод английской научной и технической литературы : Лексика, грамматика, фонетика, упражнения. Минск : Попурри, 1997. 213 с.

12. Joseph Babatunde Fagoyinbo. The Armed Forces: Instrument of Peace, Strength, Development and Prosperity. Bloomington, USA : AuthorHouse, 2013. 504 p. 


\section{ДЖЕРЕЛА ІЛЮСТРАТИВНОГО МАТЕРІАЛУ}

1. https://www.army-technology.com/

2. http://www.enemyforces.net/

3. http://www.military-today.com/

4. https://www.naval-technology.com/

5. http://www.shooting-ua.com/

\section{REFERENCES}

1. Balabin, V. V. (2018). Zhanrovo-stylova spetsyfika viiskovoho perekladu [Genre and style specifics of military translation]. Naukovyi visnyk Mizhnarodnoho humanitarnoho universytetu. Seriia: Filolohiia, 2, 67-73 [in Ukrainian].

2. Balabin, V. V. (2017). Obiekt i predmet teorii viiskovoho perekladu [Object and subject of the military translation theory]. Naukovyi visnyk Mizhnarodnoho humanitarnoho universytetu. Seriia: Filolohiia, 31 (3), 97-100 [in Ukrainian].

3. Balabin, V. V., Lisovskyi, V. M., Chernyshov, O. O. (2008). Osnovy viiskovoho perekladu (anhliiska mova) [Fundamentals of military translation (English): pidruchnyk. Kyiv: VIKNU [in Ukrainian].

4. Barhudarov, L. S. (1975). Yazyik i perevod (Voprosyi obschey i chastnoy teorii perevoda) [Language and translation (Questions of general and particular theory of translation)]. Moskva: Mezhdunarodnyie otnosheniya [in Russian].

5. Zaitseva, M. O. (2013). Osoblyvosti perekladu terminiv u tekstakh na viiskovu tematyku [Features of terms translation in the military texts]. Naukovyi chasopys NPU imeni M. P. Drahomanova. Seriia 9: Suchasni tendentsii rozvytku mov. Kyiv, 10, 96-102 [in Ukrainian].

6. Lisovskyi, V. M. (2010). Viiskovo-tekhnichnyi pereklad (anhliiska mova) [Military technical translation (English: language)]: pidruchnyk / za red. V. V. Balabina. Kyiv: VIKNU [in Ukrainian].

7. Lisovskyi, V. M. (2018). Sutnist poniattia "viiskovo-tekhnichnyi tekst" [The essence of the concept of "military-technical text"]. Molodizhna viiskova nauka u Kyivskomu natsionalnomu universyteti imeni Tarasa Shevchenka: tezy dop. Vseukrainskoi naukovo-praktychnoi konferentsii molodykh vchenykh, adiunktiv, slukhachiv, kursantiv i studentiv (Kyiv, 26 kvitnia 2018 r.). Kyiv: VIKNU, 302-303 [in Ukrainian].

8. Maltsev, D. D. (2017). Osoblyvosti perekladu viiskovoi terminolohii [Features of translation of military terminology]. Debiut: zbirnyk tez dopovidei studentiv fakultetu hretskoi filolohii za rezultatamy uchasti v Dekadi studentskoi nauky 2017 / za zah. red. dokt. polit. nauk, prof. K. V. Balabanova, dokt. ekon. nauk, prof. O. V. Bulatovoi. Mariupol, 65-68 [in Ukrainian].

9. Nelyubin, L. L. (1989). Perevod boevyih dokumentov armii SShA [Translation of military documents of the US army] (2-e izd., pererab. i dop.). Moskva: Voenizdat [in Russian].

10. Nelyubin, L. L., Dormidontov, A. A., Vasilchenko, A. A. (1981). Uchebnik voennogo perevoda [Military translation textbook]. Moskva: Voenizdat [in Russian].

11. Pumpyanskiy, A. L. (1997). Chtenie i perevod angliyskoy nauchnoy i tehnicheskoy literaturyi: Leksika, grammatika, fonetika, uprazhneniya [Reading and translation of English scientific and technical literature: Vocabulary, grammar, phonetics, exercises]. Minsk: Popurri [in Russian].

12. Joseph Babatunde Fagoyinbo (2013). The Armed Forces: Instrument of Peace, Strength, Development and Prosperity. Bloomington, USA: AuthorHouse

1. https://www.army-technology.com/

\section{SOURCES OF ILLUSTRATIVE MATERIAL}

2. http://www.enemyforces.net/

3. http://www.military-today.com/

4. https://www.naval-technology.com/

5. http://www.shooting-ua.com/ 